\title{
Custody and Religion of Minors in Malaysia
}

\author{
Mohamed Azam Mohamed Adil*
}

Child custody refers to the upbringing of a child, including the parental responsibility to provide protection, love, care, education, shelter and management. Generally, in determining who will be the legal custodian of a child, a court will first and foremost ensure that the child's welfare is wellprotected.

In Malaysia, child custody is governed by two separate laws, one for nonMuslims and one for Muslims. For non-Muslims, the Law Reform (Marriage and Divorce) Act of 1976 (Act 164) holds sway, while for Muslims it is either the Islamic Family Law Enactments of the respective states or the Islamic Family Law Act of the Federal Territories that are relevant. While the Malaysian civil court operates over the non-Muslim laws, the Syariah court operates over the Muslim ones.

Problems arise when one of the spouses in a marriage converts to Islam because conversion is recognised as grounds to dissolve a marriage under both Act 164 and the Islamic Family Law/Enactments. Also, when only one of the parties is a Muslim, both judicial systems in Malaysia have jurisdiction over the matter, thus causing a power overlap.

Both Islamic law and civil law agree, however, that in determining the custody of a child, the interest or welfare of the child is the paramount consideration. Moreover, to a certain extent the factors taken into consideration when determining the interests of a child parallel each other in both Islamic law and Civil law, except in the matter of religion. For instance, both Islamic and Civil law consider the age and gender of the child, the wishes of the child, parental ability to bring up the child, and the conduct of all parties.

In Islamic law, Muslim jurists are unanimous that when a marriage between Muslims is dissolved, the right of custody of an infant will be given to the mother. The mother has a prerogative right since she is naturally more tender and better qualified to cherish a child during infancy. The mother and her female ancestors are therefore preferred as custodians for the sole purpose of serving the best interests of the child.

Aside from welfare, religion is also an important criterion for determining child custody in Islam. Ibn Qudamah, a well-known Hanbali scholar of the $12^{\text {th }}$ century, stressed the importance of religion during custody. He said that 
"custody is aimed at looking after the child, so it should not be given in a way that will be detrimental to his welfare and his religious commitment."

Muslim jurists have dealt with this issue in different ways. According to the Syafi' $i$ and Hanbali schools of law, the custodian must profess the religion of Islam, otherwise he or she cannot gain custodial rights over the child. This decision rests on the assumption that, if a child is given to a non-Muslim custodian, the latter will influence the child's beliefs to the extent that the child may not be brought up according to the religion of Islam. Preservation of the child's religion is also one of the primary objectives prescribed under the Maqasid al-Shariah (The higher objectives of Shariah).

The Hanafi and Maliki schools, on the other hand, give a different ruling. According to them, professing the religion of Islam is not a requirement to become a custodian. Therefore, the non-converted parent has an opportunity to gain the right of custody over their child. However, there are certain restrictions to this. For example, the custodian should not influence their child on matters pertaining to religious belief, except in favour of Islam. Other restrictions include prohibitions against taking the child to places of worship other than a mosque, teaching them a religion other than Islam, and asking them to eat pork or consume alcohol.

The Hanafi and Maliki approaches to custody cases are utilised in Muslim countries like Algeria, Kuwait, Tunisia and Morocco, which allow non-Muslim parents to become custodians under certain conditions.

Malaysia, however, has adopted a stricter approach to custody. For example, section 82 of the Islamic Family Law (Federal Territories) Act 1984 (IFLA 1984) states that the first qualification necessary for custodianship is that the custodian be a Muslim.

Several problems tend to arise from this. It has been argued that Malaysia's dual system enables a spouse who contracted a civil marriage to convert to Islam and use the Syariah court as a means of claiming the custody of their children, while also evading the financial responsibilities imposed on a husband under the Civil law.

For that reason, the International Institute of Advanced Islamic Studies (IAIS) Malaysia has issued two policy issue papers, "Conversion in Malaysia: Issues and Reform Proposals" (2012) and "Penukaran Agama Kanak-kanak: Isu dan Cadangan" (2016). Each proposes policy reforms relating to conversion in Malaysia. Among the recommendations are, firstly, to ensure that the issue of conversion does not get in the way of a child's welfare or of ensuing that custodial responsibilities are met by the disputing parents. Secondly, that section 51 of Act 164 be amended to give either party to a marriage the right to file a petition for divorce. Thirdly, to establish a special branch of the judiciary 
with mixed jurisdiction, where both Syariah and Civil law judges can sit and adjudicate cases of conversion and the religious identity of a child.

\section{Notes}

* Mohamed Azam Mohamed Adil is the Deputy CEO, International Institute of Advanced Islamic Studies (IAIS) Malaysia (Email: mazamadil@iais.org.my). 